\title{
The Motif of Loss in the Literatures of Siberian Indigenous Peoples
}

Natalia A. Nepomniashchikh* Institute of Philology of SB RAS 8 Nikolaev Str., Novosibirsk, 630090, Russia

Received 01.10.2017, received in revised form 5.10.2018, accepted 08.10.2018

Siberian indigenous peoples suffered a lot throughout the $20^{\text {th }}$ century. Some of them have almost become extinct due to the globalization. The motif of loss is one of the key motifs for the literatures of Siberian indigenous peoples. Under conditions of their native culture assimilation, their languages have been disappearing, and their national identities have been blurred. That is the reason why the issue of loss is so important for them. It is implemented through the plot of a relative or an elderly person's death/dying. The death is a global metaphor for the loss of historical memory, the way of life and the culture of an entire ethnical group. The plot of loss is integral for the works of almost all Siberian authors: the Mansi, Khanty, Nivkh and Evenk people. The fact that it is common for the people belonging to the different language groups is due to the similarity in their way of living determined by the similar geographic and social factors.

The plot describing an encounter of loss is one of the most common in the works of Siberian writers.

Keywords: motifs of loss, memory, plot of a parent or a grandparent's death, images of old man, old woman.

Research area: philology.

Citation: Nepomniashchikh, N.A. (2018). The motif of loss in the literatures of Siberian indigenous peoples. J. Sib. Fed. Univ. Humanit. soc. sci., 11(10), 1593-1603. DOI: 10.17516/1997-1370-0323.

In the $20^{\text {th }}$ century small-numbered peoples of Siberia went through lot of trials and due to globalization, many of them have almost disappeared. The motif of loss is one of the key ones for all the recently put into writing literatures. Under conditions of their native culture assimilation, small-numbered peoples' languages disappearance and national identity blurring, the problems associated with the loss of national roots, traditions and beliefs come to the fore. At the level of theme, acutely conscious by

(c) Siberian Federal University. All rights reserved

* Corresponding author E-mail address: alkat@ngs.ru

This work is licensed under a Creative Commons Attribution-NonCommercial 4.0 International License (CC BY-NC 4.0). 
national authors problematics is most often implemented as a plot of loss/deprivation: death of a close relative (mother, father, grandmother or grandfather) embodying the age-old way of life, loss of memory as oblivion of the faith of ancestors and rituals, loss/gaining of a significant, from the point of view of generations continuity, thing handmade by a close relative (amulet, a ritual object), etc.

For the Shor literature as a whole, for instance, the motif of loss becomes a plotforming one: "Peoples, historically estranged from their national borders, do not create, but preserve culture, and the small-numbered peoples' languages often have the status of endangered languages, and fiction gravitates toward folklore genres. Conservative "museum" culture is compelled to protect its heritage without having enough passionate resources to create new meanings and forms. In literature this situation is complicated by the enlightening influence of other established literatures that literally impose to the first national authors aesthetic principles the indigenous literatures have not had time to develop independently. The impossibility of mastering the plot-forming paradigm of modern times qualitatively leads to the formation of specific author's writing strategies associated with bilingual thinking" (Poltoratsky, 2015: 123).

The Russian literary language was the main language of literary work for the majority of the prose works of the national authors of Siberia. Alitet Nemtushkin, Vladimir Sangi, Yeremey Aipin, Anna Nerkagi wrote and are writing novels, stories and narrations in Russian. There were no analogues written by them in the fiction of their native cultures that do not have a written language: a story, a narration and a novel do not have direct equivalents in the folklore of the Evenki, Khanty, Mansi and Nivkh literatures. Authors who were education in Leningrad and Moscow got acquainted with the genres of the story, narration and novel on the basis of Russian literature and, along with the language of both classical and contemporary Russian literature, perceived language and genre in indissoluble connection. In the created over the centuries literatures, the genre system was developed and evolved, gradually developing genre systems and adapting various genre-patterns: both in foreign language and not fiction ones for fictional tasks, meeting fictional needs, releasing the author's principle and individual consciousness, which, in the end, led to the emergence of such important for the European modern literature narrative genres as story and novel. In the recently and newly put into writing literatures, the appearance of various genres occurs somewhat differently. The future writer, withdrawn from his/her native cultural environment and educated in a foreign cultural environment, encountering with the fruits of the most diverse cultural experience is using an opportunity to synthesize his/ 
her individual experience and national culture achievements in the already prepared and successfully proved in the history of literature forms. Particularly if these forms were constantly offered as prime samples, established benchmarks and indicators of literatures maturity in the process of training. Even under conditions of the absence of any kind of "pressure from above", being in a different environment inevitably leads to adaptation, as well as voluntarily or involuntarily leads to following its cultural patterns.

Many writers of the North and Siberia were schooled by the Literature Institute. In those societies where literature arises artificially, as a result of purposeful educational and enlightenment efforts, as a result of an isolated, intensive educational process for certain individuals, it is hardly possible to speak of natural historical and literary processes. The emergence of literatures in them is a specific fact from the point of view of historical poetics. As the invention of writing in Russia during the period of its Christianization determined the ecclesiastical nature of the ancient literature, the creation of writing in the $20^{\text {th }}$ century in the period of active industrialization, collectivization and the unification of national cultures affected the general educational and ethnographic nature of the literatures of the indigenous and small-numbered peoples of the North and Siberia. Literary works of Russian classical and Soviet literature became cultural and literary models for the creation of the works of national literature.

Detailed information about the ways of separate writers' destinies formation, equated, in general, with the history of national literature, are considered in remarkable series of books named after national literature: The Khanty Literature (2002), The Nivkh Literature (2010), The Evenk Literature (2006), etc. edited by V.V. Ogryzko. In fact, these volumes, which are collections of articles by various scholars on national literatures, authors and individual works are the first systematic attempt to generalize knowledge about the development of literatures of the peoples of Siberia and the North. Sometimes the concept of national literature is identical to the work of one writer who matters, what is especially clearly seen through the example of the Nivkh literature, which is primarily represented by the name of Vladimir Sangi.

The flourishing of the newly written literatures of Siberia took place in the 196090s. It was during this period that such authors as Yu. Rytkheu, Yu. Shestalov, G. Khodzher, V. Sangi, A. Nemtushkin, P. Kile, E. Aipin, A. Nerkagi, S. Kurilov, A. Krivoshapkin, V. Ledkov, A. Passar and others become known. In the same years, a large number of works on literary theory are published, the debate about literary trends, styles, genres, their boundaries, etc. took place. The media raises issues related 
to the life of literature, and one of the most resonant issue, that agitated not only literary community, was a discussion about village prose authors. In this regard, it is noteworthy that in 1970-90 in various literatures of the peoples of Siberia (Shor, Khanty, Evenk, Nivkh, Nenets, etc.) the same motif complex of loss as in Russian "village prose" was actualized, and this is not an accidental coincidence. It was in that period that it became possible, even if not out loud, only partially, but still start raising the issues that small-numbered peoples faced in the $20^{\text {th }}$ century; not always successful results of the previously pursued policy of their alienation from the traditional way of life and housekeeping became visible and tangible, the need for an artistic interpretation of the global changes that have taken place arose. Native folklore, that did not have such problematics, could hardly serve as a source and a guide for the creation of a complete work of fiction, it becomes a rich material used as a marker of national culture, and Russian village prose with its nostalgic mood, with its focus on the description of the outgoing traditional culture and environmental themes, becomes the closest in its problematics to the representatives of national cultures.

The main theme of "village prose" and its emotional message was the regret about the lost traditional culture, principles and way of life, rooted in the history of the people, and the old times were interpreted as a golden age, according to N.V. Kovtun, "the pathos of the work of the village prose authors can be expressed by the aphorism of E. Zamyatin: "Our future is in the past" (Kovtun, 2009: 211). Her attention was mainly focused on the tragedy of the ancestral roots' loss. Accordingly, the plot and the motif body of the "village prose" works mainly include motifs related to loss, deprivation, rupture and death, as well as memory. Almost in every work by different authors, whether it is V. Astafyev, V. Rasputin, V. Belov, F. Abramov, V. Shukshin and others, an important place in the narration is occupied by unforgettable memories, detailed descriptions of the once habitual village realia, usual once, but almost disappeared peasant activities and occupations. Characters represented by the older generation are most often the keepers of historical, peasant and ancestral memory. These are old worldly-wise men and women, who are opposed to the rational and pragmatic mind of modern youth leaving their native places, consciously oriented toward the seemingly more attractive achievements of civilization. Old people, unlike young ones, leave their native places with great difficulty and pain, for many of them such separation is like death and not only metaphorical.

A special place in the "village prose" is given to the concept of home as a family home, an abandoned and empty house-izba becomes a symbol of a dying village and 
an age-old way of life. It is noteworthy that one of the parts of the famous trilogy by F. Abramov is entitled "The House" and the title of one of the parts of the trilogy by G. Hodzher "The Amur Wide" - "The End of the Big House". The time of action in the books is different: if F. Abramov writes about his contemporary reality, speculating it in relation to the age-old ideal, G. Hodzher addresses to the past of his people from the standpoint of a new ideology, which considers all those changes brought to the life of the indigenous Siberian peoples by the Soviet power to be progressive. The goals and tasks of writers coincide when it is necessary to show the breakdown of the traditional way of life, the destruction of the foundations of the life of people (albeit with different ideological assessments of the fact itself). They resort to the same images, motifs and plots: the motif of disintegration of the family way of life that has helped to survive in difficult natural and social conditions for centuries becomes central, the loss of ancestral consciousness is linked to the new reality that invades into the life of traditional society: "The late prose by F. Abramov and V. Rasputin, as well as the "village literature" as a whole, is developed under the sign of "the end". The themes of the enemy force invasion, the death of the house/temple, self-immolation and the flood are prevailing. Pristine characters are changed as well: the feat of the spirit, the struggle for the idea as a traditionally male feat is supplemented by the feat of the woman-warrior, which is especially evident in the late work by Rasputin" (Kovtun, 2010: 93-102).

The life of the indigenous peoples of Siberia, like any traditional cultures, is associated with natural cycles, with traditional crafts and methods of obtaining food and with ancient beliefs, their culture is composed of folklore and shamanism. All this determines the contrast between the cultures of the northern and Siberian peoples of the technocratic civilization, and in the literatures, it manifests nostalgia for the former harmonious relations between man and nature, the age-old way of life, the desire to see only the best and to create their own myth about the golden age. As well as in the works of the "village prose authors" there is a certain image of a speculative utopian ideal that concerns the past, and the authors of the North and Siberia have their own ideas about the legendary golden past of their peoples, which is most often represented in the literary works by folklore legends, tales and songs told by the older generation. The myth of what was lost and long gone fitted well into the literary pattern that the "village prose" offered: an essay, a story, a narration, a narration in stories and a novel, where narrations about household activities, everyday life, family history and its extinction, plots of old men and women' death, escape from their native places and belated return to the ashes, the motifs of loss and memory become central. 
Finally, those works of the national authors of Siberia, where the national tragedy is overcome through personal experience, turned out to be the most ideologically and aesthetically significant. Among them, it is possible to distinguish those where the narrative technique of depicting the past through the prism of a child's perception is used, and the narration is composed as a chain of memories: "Properties of the Soul" by P. Kile, "I Dream of Heavenly Deer" by A. Nemtushkin, "At the Fading Hearth" by E. Aipin, and "Little America" by G. Keptuke. According to the genre the last three are narrations in stories, and they exist in different versions and compositions. Among the literary samples of this genre, narration in stories "The Last Bow" by V. Astafyev is the closest to them. As well as in Astafyev's story, the stories are linked together by a complex of common motifs, consistent characters and migrating toponyms. In the center of the story "The Last Bow" is a boy, the story of his growing up, his home, his grandmother, various incidents and events of his childhood. The stories by A. Nemtushkin, E. Aipin and G. Keptuke are arranged in the same way. The growing up of a child next to a grandmother or grandfather in them is based on the age-old traditions of ancestors, and the elders become a source of knowledge about the native culture, almost lost by them. The death of a close adult (a grandmother or a grandfather) is not only an irreparable loss of a close relative, but also a global metaphor for the loss of one's roots, native culture and the way of life. So, the character of the book by Nemtushkin, the boy Armachu, is sent to a boarding school after his grandmother's death, and he will return to his native land not any time soon.

Old men and women have knowledge that becomes inaccessible, unknown to the younger generation. The strength of their faith and their knowledge accumulated over the centuries, their everyday wisdom and everyday ethics determine the spiritual development of the narrating authors, do not allow them to break and interrupt generational bridge, force them to start writing in their adulthood to fix, capture and remember what is irreversibly disappearing. A shaman, old man Efrem in the book by E. Aipin, for the first time, during the shamanistic ritual opened a little child the truth about the interconnection of everything in this world, about interdependence, about the harmony of all components of the universe and its unity.

In the cultures of many peoples of Siberia death does not mean the irrevocable end of existence, it is only a transition to another world where your ancestors are waiting for you, and everyone is determined how long it takes to come to them. Here, it is possible to find parallels between Russian "village prose", which uses folklore and mythological motifs in depicting death and representations about it among old men and 
women, and mythological ideas about death among Siberian peoples. N.N. Kotenko made a very interesting observation, that the description of the death of old woman Anna in "The Last Term" by V. Rasputin in many respects coincides with the text of his earlier story "Eh, Old Woman", written on the basis of his direct communication with the representatives of indigenous peoples when he was a correspondent of the Krasnoyarsk newspaper: "So, the plot of a short story "Eh, Old Woman" (1966) is based on the death of an old Tofalar woman, who believed that the souls of the dead continue to communicate with those who live. This story is also of interest due to the fact that the image of the Tofalar shamaness is endowed with the traits of character which were later transferred to the righteous Anna from the "The Last Term". Here we can find a number of formulations, which later, almost without changes, were incorporated into the text of the story (Kotenko, 1988: 22). The parallel of plot about the death of the Tofalar shamaness and the Russian old woman from the village arising in the literary work of one author speaks of the inner affinity of traditional cultures, the typological closeness of both described life situations themselves, and the similarity of their vision by author and literary embodiment.

In the stories and narrations of the national Siberian literatures authors, as well as in the Russian "village prose", there is often a repetitive plot: a wise and respected old man/woman (sometimes a shaman or a shamaness, but not necessarily) dies, but before that he/she is preparing for his/her death. Knowing about the imminent arrival of the last hour, the character does not fear of it at all, he/she is waiting for the time doing different activities, although the types of these activities can differ diametrically. Thus, in the book by A. Nemtushkin "I Dream of Heavenly Deer", the old man makes his coffin beforehand, and in the story "The Last Will of the Shamaness" the shamaness falls into a kind of lethargy for ten days to make a preliminary trip to the Lower World. For a lot of people, the shamaness' request not to bury her before the characteristic smell appearance seems unreasonable, but the will of the shamaness was performed due to the girl Vera, whom the shamaness had chosed as her successor as she did not have her own children. Symbolically, the name of the girl is Russian, it has a meaning, it was only Vera who believes the shamaness and tells about her request not to bury her immediately. The old woman had been laying in a tepee for ten days, and finally, the people decided to bury her. In the community centre where the coffin with the body was brought, the old woman suddenly sat down and "came to life", having frightened the people. It turned out that the shamaness had been travelling for these ten days, visiting the place "where we come from." Immediately after telling the story of her trip 
to the Lower World, she asks to bury her in the trees according to the old custom of the Evenks, it is an issue of a traditional burial that has not been observed by anyone, but her will has been performed. The end of the story remains open: in forty days, Vera finds a belt of the shamaness among her things and there were neither a body of the deceased nor any of her belongings in the tree-trunk on the trees. The fortieth day after the death which, according to the Russian tradition is significant, is also of interest: Vera as if unites two different cultures in herself, and it is unknown which one she will choose. The reader will have to decide, what kind of inexplicable phenomenon, known only to the dedicated shamans it was, and whether the last shamaness Lolbikte will be replaced by Vera who has Evenk blood of the same tribe as the shamaness, the tribe of woodpeckers.

Preparation for the impending death, knowledge of the "time" is found in many traditional cultures, which include the cultures of the peoples of Siberia. But this is not always understood by the outsiders and the people of a new type of thinking. So, in the story by A. Nemtushkin an "authorized" person, who came to the settlement, makes a young men break down the coffin the old man Madu had made for himself. The old man is distressed, as he had been busy constructing this "box" for a week. And, as it turns out, the coffin was destroyed in vain: the old man really dies the same evening his coffin was destroyed. Madu is not angry with the authorized person. He understands that according to the new order it is not customary for a person to equip him/herself to the Lower World. He only worries that no one will pay him last respects according to the old customs, as the only relative, his nephew, does not really observe them, for him this is just another reason to get drunk. In connection with the old man's death, the question of the following/non-following the ancient sacred traditions and customs repeatedly arises. The motif of breaking the precepts of ancestors and interruption of ancient traditions, as a rule, takes place along with the motif of death, being an integral part of the plot of the wise old man's death.

The plot is also interesting in its "inverted form" where the loss of tradition turns into a conscious choice of a new life. The story "The Last Tribute to Custom" by V. Sanga is devoted to the situation of return, but the impossibility to return to the old cultural environment. A young teacher who arrives in the village comes from these places. After bear hunting with one of his relatives, he realizes that although he has passed the test, he cannot and does not want to live following the long-gone laws and leaves without telling anyone. Connection with the past is lost forever, the former custom, once serving to test the young man's readiness to take care of the family, 
degenerated into a banal boast and needlessly dangerous fun. There is no old way of life, and the new one does not meet his ideas about life, and the young man prefers to flee to the new world he is acquainted with. In the prose by V. Sangi, the motif of violating the old custom is continuous and is connected with the motif of loss. In "The Wedding of the Kevongs", the violation of the custom turns for the main character into a loss of the bride, in contravention of the old requirements, symbolizing disintegration of the former system of values and the discord in the once harmonious way of life. In "Izgina", the old man dying in the winter taiga is making an unprecedented step, breaking apart steel traps put to catch his beloved fox. He dies performing this action.

Common motifs characteristic for the prose by Alitet Nemtushkin, Yeremey Aipin, Vladimir Sanga, Galina Keptuke and other authors are determined by the fact that these are the books about the forgotten traditions of their peoples, about the tragedy that they faced as a result of the historical twists and turns of the $20^{\text {th }}$ century, the forced imposition of a settled way of life to lots of peoples in the territory of Siberia, the replacement of traditional hunting, fishing, reindeer herding and works by collective farming. They mainly correlate to the tragic pages of the books by village prose authors. Both turn to the image of the radiant past. Both are characterized by the desire to give detailed description of the lost way of life, the experience supported by the centuries-old life of a lot of generations. As well as in the "village prose" old men and women become the symbol of the lost world, its spiritual center. According to the researcher, village prose authors "see the symbol of the loss of their way of life in old people's death" (Parthe, 2004: 16). Passing away, the death of old men and women in the literary works of the national authors of Siberia become a similar metaphor.

There are two grandmothers in the book by Yeremey Aipin "At the Fading Hearth": in the chapter "Grandmother's Sister" the narrator tells about how a grand-aunt helped them, the orphans, who stayed without a mother, and how he knew nothing about her death and did not think about it until certain time, and how, being an adult, he realizes that she helped them to survive. In some ways, the character's reflections resonate with the similar thoughts from the final part of V. Astafyev's "The Last Bow". As well as "The Last Bow", the process of book creation was long and was developed as a conceptual whole from the stories, some of which were previously published separately in different collections. In the introduction "How This Book Was Created", which has the subtitle "Elegy for the Reader," E. Aipin says that this is a book "about the people passing away from life, about the people doomed to a slow demise" (Aipin, 1998: 5). 
The mission of literature in this situation is to preserve the memory about the people, their culture and their ancestors.

National cultures, influenced by Russian culture, partially assimilated and partially absorbed the elements, ideas, the principles of fiction and the ways of representation that could be the source for the new, to become an impulse to their development in the context of the world and multinational Russian culture. The issue of preserving the national identity was critical, and it was this problem that became central for the work of many national writers, both in the Russian "village prose", which was expressed in the motifs of memory and stories about old men and women, as well as historical, peasant and generic memory carriers and keepers. Worldly wisdom and age-old traditions that were carefully guarded by these old men and women are opposed to the rational and pragmatic mind of modern youth leaving their native places. If old people stick to the age-old way of life and collective traditions, the youth is consciously oriented toward the seemingly more attractive achievements of civilization, they already have a sense of individualism that is in conflict and contradiction with the established preconceptions of the ancestors ("White Reindeer Moss" by A. Nerkagi, "The Death of the Shamaness" by A. Nemtushkin, "The Last Tribute to Custom", "Izgina" and "At the Origins" by V. Sangi). Old people, unlike young people, leave their native places with great difficulty and pain, for many of them such separation is like death and not only metaphorical.

Thus, the motifs for loss, ancestral and historical memory, which, apart of literal and autodocumentary content have a different, figurative meaning, become a global metaphor for the loss of the traditional way of life and irretrievable disappearance of the ancestral culture, saturate literary work of different authors, which is determined by the common destiny of these peoples in the $20^{\text {th }}$ century.

\section{References}

Aipin, Y. (1998). U gasnushchego ochaga [At the Fading Hearth]. EkaterinburgMoscow.

Kovtun, N.V. (2009). Derevenskaia proza v zerkale utopii [Village Prose in the Mirror of Utopia]. Novosibirsk, SB RAS.

Kovtun, N.V. (2010). Iurodskoe stranstvie v poetike F. Abramova [Holy Fool's Wandering in F. Abramov's Poetics], In Sibirskii filologicheskii zhurnal [Siberian Journal of Philology], 3, 93-102.

Kotenko, N.N. (1988). Valentin Rasputin: ocherk tvorchestva [Valentin Rasputin: Essay on Literary Work]. Moscow. 
Parthe, K. (2004). Russkaia derevenskaia prosa: svetloe proshloe [Russian Village Prose: The Radiant Past]. Tr. from English. Tomsk.

Poltoratsky, I.S. (2015). Siuzhetoobrazuiushchie funktsii motiva utraty v shorskoi literature [Plot-forming Functions of the Motif of Loss in Shor Literature], In Sibirskii filologicheskii zhurnal [Siberian Journal of Philology], 4.

\title{
Мотив утраты в младописьменных литературах Сибири
}

\author{
Н.А. Непомнящих \\ Институт филологии СО РАН \\ Россия, 630090, Новосибирск, ул. Николаева, 8
}

В ХХ веке на долю мальх народов Сибири выпало немало испьтаний, многие из них под воздействием глобализации почти исчезли. Мотив утрать - один из ключевых для младописьменных литератур. В ситуачии ассимилящии родной культуры, исчезновения языков мальхх народов, размывания национальной идентичности на первый план выходит проблематика, связанная с утратой, которая реализуется как сюжет смерти/умирания близких родственников или старика/старухи. Смерть становится глобальной метафорой утраты исторической памяти, традиционного образа жизни, безвозвратного исчезновения исконного быта и культуры. Сюжет утраты является общим для писателей-представителей разных сибирских народов: манси, ханты, нивхов, эвенков. Подобное совпадение сюжета в произведениях писателей, принадлежащиих к разным языковым группам, обусловлено социальными факторами, географией расселения, сходным бытом, условиями жизни.

Сюжет утраты можно считать одним из типических для младописьменных литератур в целом.

Ключевые слова: мотив утрать, мотив памяти, сюжет о смерти отиа/матери/ бабушки, образы старика/старухи.

Научная спецฺиальность: 10.00.00 - филологические науки. 